\title{
PENELITIAN TINDAKAN KELAS DENGAN MENGGUNAKAN SPSS BAGI GURU SMK SANTO LEO JAKARTA
}

\section{Urbanus Ura Weruin', Lerbin Aritonang², Miharni Tjokrosaputro ${ }^{3}$, dan Herlina Budiono ${ }^{4}$}

\author{
${ }^{1}$ Jurusan Akuntansi, Universitas Tarumanagara Jakarta \\ Surel:urbs.weruin@gmail.com \\ 2 Jurusan Manajemen, Universitas Tarumanagara Jakarta \\ Surel: lerbina@fe.untar.ac.id \\ ${ }^{3}$ Jurusan Manajemen, Universitas Tarumanagara Jakarta \\ Surel: miharnit@fe.untar.ac.id \\ ${ }^{4}$ Jurusan Manajemen, Universitas Tarumanagara Jakarta \\ Surel: herlinab@fe.untar.ac.id
}

\begin{abstract}
Classroom Action Research (CAR) is a scientific observation of classroom learning practices. As part of action research, research is intended as input, evaluation, and improvement of the quality of learning in the classroom. CAR training is important and relevant for the following reasons. First, CAR can improve the quality of education through improving the quality of the learning process. Second, motivating teachers to research and produce scientific works from the environment of daily learning activities. Third, improve the competency standards of teachers; especially pedagogical competence and professional competence. Fourth, stimulate the critical power and sensitivity of teachers to the dynamics of classroom learning. The Cycle of CAR starts from the planning, implementation, observation, and reflection stages. The instrument to analyze classroom action research data is SPSS. CAR Training using SPSS is needed because some teachers are not familiar using SPSS to measure the learning process in class. The teachers of SMK Santo Leo felt the need to receive this training. This PKM activity was carried out to enhanced teacher's knowledge and skills to used SPSS in classroom action research. The results were that the teachers appreciated this activity and welcomed it positively. They are able to understand classroom action research procedures; able to compile a research proposal; compile a research questionnaire; and able to determine data analysis tools using SPSS. The following training stage is to provide assistance to teachers in conducting research practices and analyzing data so the theoretical knowledge and skills they acquire can be applied.
\end{abstract}

Keywords: Classroom action research, research proposal, SPSS

\begin{abstract}
ABSTRAK
Penelitian Tindakan Kelas (PTK) merupakan observasi ilmiah terhadap praktik pembelajaran di kelas. Sebagai bagian dari action research, penelitian terhadap kegiatan pembelajaran tersebut dimaksudkan sebagai masukan, evaluasi, perbaikan, dan peningkatan mutu pembelajaran dalam kelas. Pelatihan PTK merupakan sesuatu yang penting dan relevan karena alasan-alasan berikut. Pertama, PTK dapat meningkatkan mutu pendidikan melalui peningkatan mutu proses pembelajaran. Kedua, memotivasi para guru untuk meneliti dan menghasilkan karya-karya ilmiah dari lingkungan kegiatan pembelajaran sehari-hari dalam kelas. Ketiga, meningkatkan standar kompetensi para guru; khususnya kompetensi pedagogik dan kompetensi profesional. Keempat, merangsang daya kritis dan kepekaan para guru terhadap dinamika pembelajaran di kelas. Siklus PTK dimulai dari tahap perencanaan, pelaksanaan, observasi, dan refleksi. Instrumen yang dapat dipakai untuk menganalisis data PTK sehingga hasil yang diperoleh akurat adalah dengan menggunakan SPSS. Pelatihan PTK dengan menggunakan SPSS perlu dilakukan karena sebagian guru belum terbiasa menggunakan SPSS untuk mengukur proses belajar di kelas. Guru-guru SMK Santo Leo merasa perlu mendapatkan pelatihan tentang penelitian tindakan kelas dengan menggunakan SPSS. Maka kegiatan PKM ini dilakukan untuk memberikan pengetahuan dan keterampilan menggunakan SPSS dalam melakukan penelitian tindakan kelas. Hasilnya adalah guru-guru mengapresiasi kegiatan PKM ini dan menyambut positif. Mereka semakin mampu memahami prosedur penelitian tindakan kelas; mampu menyusun proposal penelitian; menyusun kuesioner penelitian; serta mampu menentukan alat analisis data dengan menggunakan SPSS. Tahap pelatihan berikut yang perlu dilakukan adalah melakukan pendampingan terhadap para guru dalam melakukan praktik penelitian dan menganalisis data sehingga pengetahuan dan keterampilan teoretis yang mereka peroleh dapat diaplikasikan.
\end{abstract}

Kata Kunci: Penelitian tindakan kelas, proposal penelitian, SPSS. 


\section{PENDAHULUAN}

Penelitian Tindakan Kelas (PTK) adalah observasi ilmiah terhadap praktik pembelajaran di kelas. Kegiatan pembelajaran yang melibatkan guru dan murid di kelas tersebut ingin dievaluasi secara ilmiah, guna memahami hakikat, makna, kendala, tantangan, prospek, dan hasil proses pembelajaran yang dilakukan. Sebagai bagian dari action research, penelitian terhadap kegiatan pembelajaran tersebut dimaksudkan sebagai masukan, evaluasi, perbaikan, dan peningkatan mutu pembelajaran di kelas. Tetapi sebagian orang mereduksi penelitian tindakan kelas pada upaya mengkaji indikator keberhasilan proses dan hasil pembelajaran guru dan murid di sekolah. Sejatinya, per definisi, penelitian tindakan kelas bukan alat untuk mengukur hasil belajar melainkan alat untuk mengukur proses pembelajaran (tindakan) agar mencapai hasil pembelajaran yang optimal.

Dalam praktik, penelitian tindakan kelas misalnya bertujuan untuk menguji secara ilmiah (metodis, sistematis, koheren, rasional, empiris) apakah pembelajaran daring efektif meningkatkan pengetahuan siswa? Apakah proses pendampingan secara personal oleh guru kepada siswa mampu meningkatkan motivasi belajar siswa? Seberapa signifikan tugas-tugas yang diberikan guru mampu meningkatkan pengetahuan siswa? Apakah metode pembelajaran dengan diskusi atau dengan memberi begitu banyak tugas mampu meningkatkan pengetahuan siswa? Mengapa siswa kurang mampu mengungkapkan pendapatnya dalam menjawab pertanyaan di kelas padahal guru sudah memberikan berbagai instruksi dalam berbagai cara? Apakah metode pembelajaran jarak jauh mampu memotivasi siswa untuk mandiri dalam belajar? Dan sebagainya....dan sebagainya... Semua pertanyaan ini dapat dijawab secara ilmiah dengan menggunakan metode yang dapat dipertanggungjawabkan secara ilmiah. Ini yang disebut dengan penelitian tindakan kelas. Salah satu perangkat ilmiah yang dipakai untuk mengukur efektifitas tindakan di kelas adalah dengan menggunakan statistik. Maka kami ingin melakukan kegiatan Pengabdian Kepada Masyarakat (PKM) dengan tema"Pemanfaatan SPSS dalam Penelitian Tindakan Kelas".

Salah satu pertanyaan pokok terkait dengan penelitian adalah seberapa penting peran penelitian bagi masyarakat? Weil (2009) dan Czarl \& Belovecz (2007) menyatakan bahwa peran penelitian sangat penting bagi perkembangan teknologi dan peningkatan produktivitas. Jika kemudian disinyalir bahwa produktivitas masyarakat Indonesia rendah, salah satu sebabnya adalah kuantitas dan kualitas pendidikan yang masih sedikit dan rendah. Maka dampak penelitian bagi perkembangan teknologi dan produktivitas pun masih tergolong rendah. Salah satu upaya yang perlu ditempuh untuk meningkatkan jumlah dan kualitas penelitian adalah dengan mengadakan pelatihan penelitian bagi berbagai kalangan pendidikan dan akademisi, termasuk bagi para guru.

Pelatihan penelitian bagi para guru merupakan kegiatan yang mendesak untuk dilakukan karena mutu pendidikan, terutama pendidikan menengah, sebagian bergantung pada kualitas dan profesionalitas para guru. Salah satu kualitas yang dibutuhkan adalah pengetahuan dan kemampuan dalam melakukan penelitian; khusunya penelitian tindakan kelas (PTK). Sebagai pendidik, seorang guru tidak hanya dituntut untuk menguasai dan menerapkan proses pembelajaran yang berkualitas, melainkan juga menilai, melatih, mengevaluasi, dan membimbing para murid atau peserta diri untuk terus meningkatkan pengetahuan dan keterampilan (UU RI Nomor 14, 2005).

Setiap guru wajib memenuhi standar kualifikasi akademik dan kompetensi guru yang berlaku secara nasional, yang meliputi kompetensi pedagogik, kompetensi kepribadian, kompetensi sosial, dan kompetensi professional (Peraturan Menteri Pendidikan Nasional Nomor 16 tahun 2007). Salah satu upaya meningkatkan kompetensi dimaksud adalah melalui penelitian tindakan kelas atau sering dinamakan PTK. 
Penelitian Tindakan Kelas (disingkat PTK) atau Classroom Action Research (CAR) adalah penelitian yang dilaksanakan oleh guru di dalam kelas dengan tujuan untuk meningkatakan kualitas proses belajar. Maka PTK dapat dianggap sebagai evaluasi ilmiah dan objektif terhadap proses belajar di kelas. Menurut Arikunto, dkk (2006), penelitian tindakan kelas adalah upaya terencana untuk mencermati kegiatan belajar-mengajar antara guru dan murid di dalam kelas. Hasil dari penelitian tindakan kelas dapat memberikan cara dan prosedur pembelajaran yang baru. Untuk itu cara pembelajaran yang konvensional atau yang berlangsung begitu saja, perlu terus dievaluasi, diperbaiki, dan ditingkatkan melalui penelitian tindakan kelas. Melalui evaluasi, perbaikan, dan peningkatan proses belajar, profesionalisme guru tidak hanya meningkat melainkan juga prestasi perserta didik pun meningkat. Menurut O'Brian (Mulyatiningsih, 2011), penelitian tindakan kelas berangkat dari identifikasi permasalahan yang dialami oleh siswa atau guru di dalam kelas. Berhadapan dengan masalah tersebut, guru diharapkan mampu mengatasinya. Dengan PTK, guru bertindak bukan hanya sebagai pendidik, melainkan juga sebagai peneliti.

Tujuan akhir pelaksanaan PTK itu sendiri bukan sekedar demi meningkatan kemampuan guru dalam meneliti, melainkan untuk meningkatkan hasil belajar siswa (Yuliwati, Suprihatiningrum, Rokhimawan, 2012; Wardhani, 2014). Melalui penelitian, guru diharapkan dapat menemukan solusi terhadap masalah yang ditemukan, sehingga proses pembelajaran dapat berlangsung optimal (Rahayu, 2007). Proses yang optimal akan membawa hasil yang optimal pula.

Maka hasil PTK diharapkan mampu memberikan inovasi-inovasi terbaik guna meningkatkan kualitas proses pembelajaran dan pada akhirnya juga kualitas peserta didik. Mengacu pada Yuliwati, Suprihatiningrum, Rokhimawan (2012), terdapat beberapa alasan lain mengapa PTK diperlukan oleh para guru untuk meningkatkan profesionalitasnya, antara lain:

a. PTK dapat merangsang daya kritis dan kepekaan para guru terhadap dinamika pembelajaran di kelasnya;

b. PTK dapat mendorong guru untuk menjadi peneliti yang kreatif yang mampu menemukan solusi atas permasalahan actual yang muncul di kelas;

c. Hasil PTK tidak saja dapat dimanfaatkan oleh guru sebagai peneliti, namun juga oleh rekan guru lain yang mungkin mengalami masalah yang sama. Selain itu hasil PTK juga dapat digunakan oleh pihak sekolah, pemerhati pendidikan, dan pemerintah.

Dengan demikian PTK penting dilakukan untuk para guru. Tidak hanya untuk meningkatkan profesionalitas para guru melainkan juga meningkatkan mutu pembelajaran di kelas. Peningkatan mutu pembelajaran di kelas pada akhirnya juga dapat meningkatkan kualitas lulusan.

Tetapi persoalannya adalah tidak semua guru memahami penelitian tindakan kelas. Dalam banyak hal mereka lebih mengandalkan 'kebiasaan' proses belajar dan evaluasi belajar secara sederhana dari pada mengevaluasinya secara ilmiah dengan menggunakan metode penelitian yang teruji untuk meningkatkan kualitas belajar di kelas. Kondisi ini dialami juga oleh guru-guru SMK Santo Leo Jakarta.

Dari hasil wawancara dengan kepala sekolah SMK Santo Leo, diketahui bahwa guru SMK Santo Leo mengenal adanya Penelitian Tindakan Kelas namun untuk pelaksanaan penelitian belum disertai dengan pelatihan menggunakan software. Maka, Guru SMK Santo Leo akan diberikan pelatihan mengenai penelitian tindakan kelas (PTK).

Target minimal yang dihasilkan adalah para guru menghasilkan draft proposal penelitian tindakan kelas untuk kemudian dipraktikan dan dianalisis menggunakan SPSS. Periode berikutnya akan dilanjutkan apabila memungkinkan untuk kegiatan PKM berikutnya untuk diberikan pantauan dan 
panduan lebih lanjut atas pelaksanaan penelitian tindakan kelas. Sehingga dengan demikian, bentuk kegiatan PKM yang akan diberikan dan dilaksanakan berupa pembuatan modul pelatihan penelitian tindakan kelas sebagai panduan bagi guru SMK Santo Leo, dan pembuatan draft proposal penelitian tindakan kelas jika memungkinkan dari waktu yang tersedia serta kerjasama dari pihak guru yang bersedia mengirimkan email untuk proses selanjutnya dari draft proposal guru dimaksud.

\section{METODE PELAKSANAAN PKM}

Pelatihan penelitian tindakan kelas yang kami lakukan bagi guru-guru SMK Santo Leo menggunakan model Kurt Lewin (Mulyatiningsih, 2011). Seperti dijelaskan oleh Lewin, penelitian tindakan kelas dilakukan dalam empat komponen yakni dimulai dari perencanaan, tindakan, pengamatan, dan refleksi. Ide Lewin ini kemudian dikembangkan oleh Hopkins.

Menurut Hopkins (1993), penelitian tindakan kelas diawali dengan perencanaan tindakan (Planning), penerapan tindakan (action), mengobservasi dan mengevaluasi proses dan hasil tindakan (Observation and evaluation). Sedangkan prosedur kerja dalam penelitian tindakan kelas terdiri dari empat komponen, yaitu perencanaan (planning), pelaksanaan (acting), pengamatan (observing), dan refleksi (reflecting), dan seterusnya sampai perbaikan atau peningkatan yang diharapkan tercapai (kriteria keberhasilan). Penjelasan langkah-langkah penelitian tindakan kelas adalah sebagai berikut:

1. Perencanaan (Planning). Langkah pertama PTK dimulai dengan merencanakan proses pembelajaran yang sistematis dan terukur. Tahap ini bisa dimulai dengan menentukan materi pembelajaran, menetapkan langkah-langkah pembelajaran, serta memilih dan membuat media pembelajaran. Tahap ini termasuk dalam tahap persiapan atau rencana proses pembelajaran.

2. Pelaksanaan Tindakan (Acting). Pada tahap ini, kegiatan pembelajaran dilakukan sesuai rencana pembelajaran yang telah dipersiapkan. Sedapat mungkin proses pembelajaran dilakukan sesuai dengan perencanaan secara terukur sehingga kemudian dapat dievaluasi.

3. Observasi (Observe). Observasi dilakukan untuk melihat apakah kegiatan dilakukan sesuai rencana yang telah dipersiapkan. Observasi dapat dilakukan dengan menjawab pertanyaanpertanyaan seperti: apakah kegiatan dapat mengatasi problem atau masalah yang dihadapi; apakah ada penyimpangan-penyimpangan dari rencana semua; apakah hasil yang diharapakan tercapai; apakah metode yang dipilih cocok dengan kondisi kelas; apakah kemampuan peserta didik meningkat; dan sebagainya. Kegiatan observasi dapat dilakukan dengan cara memberikan lembar observasi atau dengan cara lain yang sesuai dengan data yang dibutuhkan.

4. Refleksi (Reflecting). Tahap refleksi merupakan tahap evaluasi secara keseluruhan. Yang perlu dievaluasi adalah kegiatan dan hasil atau dampak yang dicapai dari kegiatan tersebut. Hasil evaluasi akan menunjukkan apakah terjadi perubahan dalam bentuk peningkatan proses dan hasil belajar secara signifikan pada peserta didik. Berdasarkan refleksi ini suatu perbaikan tindakan dalam bentuk re-planning dapat dilakukan. Refleksi menjadi dasar bagi perencanaan dan pelaksanaan tindakan berikut.

Pelaksanaan pengabdian kepada masyarakat bagi SMK Santo Leo direncanakan dalam dua tahap (siklus), seperti tampak pada Gambar 1. Tahap pertama adalah memberikan pemahaman teoritis tentang jenis-jenis penelitian, bagaimana menyusun proposal, dan menentukan model SPSS yang akan dipergunakan. Sementara tahap kedua direncanakan untuk melakukan penelitian berdasarkan proposal yang sudah dibuat untuk kemudian dianalisis menggunakan SPSS. Tetapi pengabdian kepada masyarakat yang dilakukan di SMK Santo Leo baru berjalan pada tahap pertama (Siklus 
1). Untuk tahap kedua (siklus 2) mesti perlu dirundingkan kembali bersama kepala sekolah dan guru-guru yang ada di lokasi karena tidak mudah mengumpulkan guru di tengah pandemic Covid19.

Proses pelaksanaan pengabdian kepada masyarakat bagi guru SMK Santo Leo sendiri dilakukan dalam beberapa tahap.

Tahap 1: Menjelaskan tentang konsep-konsep pokok penelitian, penyusunan proposal penelitian, dan penentuan alat analisis statistic (SPSS) yang akan digunakan.

Tahap 2: Menjalankan penelitian berdasarkan proposal yang sudah dibuat untuk kemudian dianalisis dengan menggunakan SPSS.

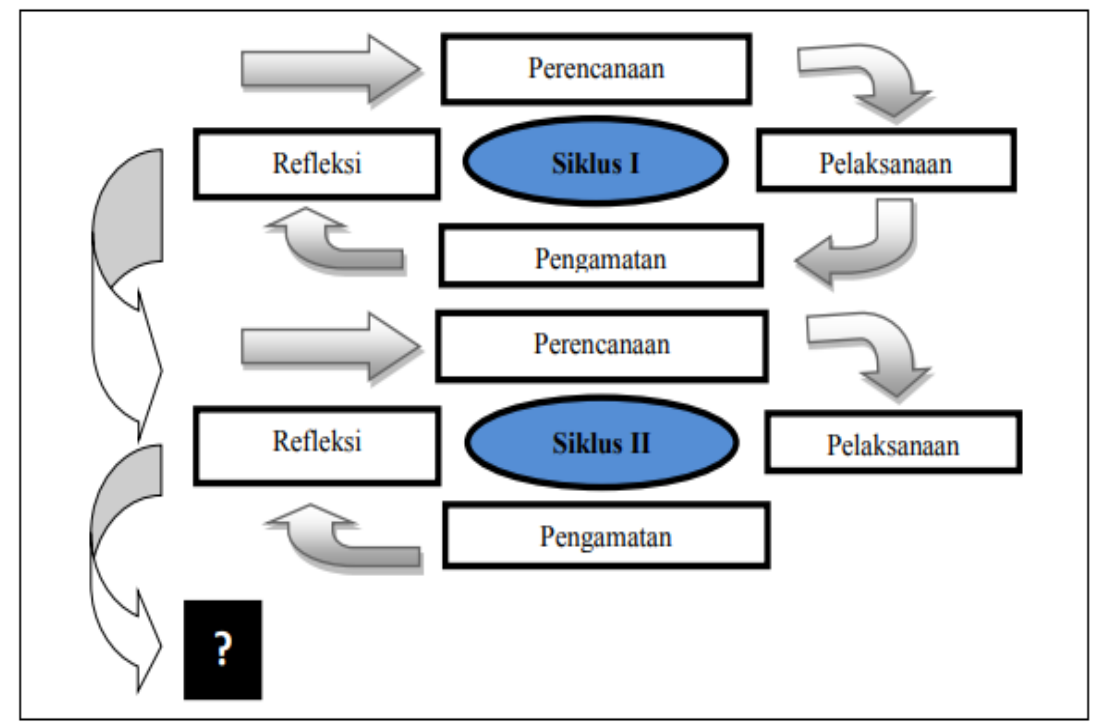

Gambar 1. Model Pemahaman

Metode pelaksanaan PKM sendiri dilakukan melalui ceramah, diskusi, dan tanya jawab. Karena situasi tidak memungkinkan untuk tatap muka maka semua proses dilakukan secara daring dengan menggunakan platform zoom meeting. Pelaksanaan PKM via Zoom dapat dilihat pada Gambar 2.

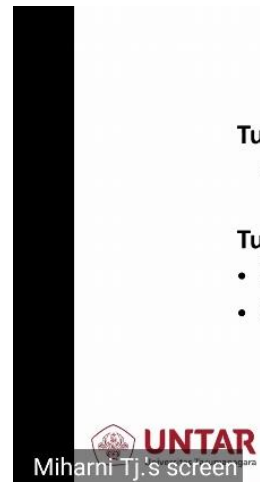

\section{TUJUAN PENDIDIKAN DAN PTK}

Tujuan pendidikan: mengubah perilaku peserta didik

Tujuan PTK:

- Perubahan perilaku: intervensi

- PTK: mengukur keberhasilan intervensi

PRE $=>$ INTERVENSI $=>$ POST

$$
\text { - Par PA. }
$$

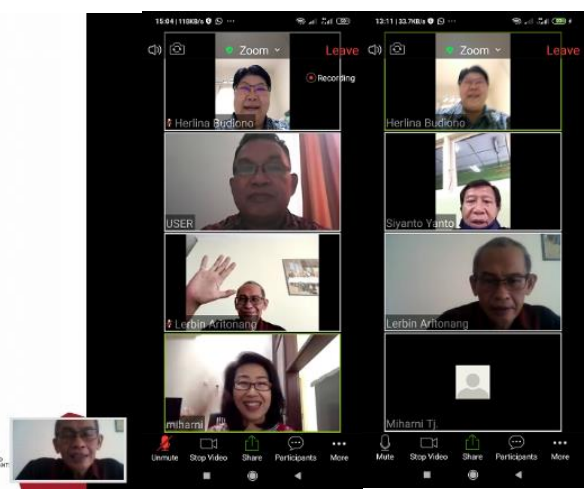

Gambar 2. Pelaksanaan PKM via Zoom

Materi yang diberikan dimulai dengan menjelaskan secara garis besar tentang prosedur sebuah penelitian ilmiah, tujuan penelitian, jenis-jenis penelitian (termasuk penelitian tindakan kelas), menyusun proposal penelitian (memilih dan merumuskan judul penelitian, latar belakang penelitian, menemukan dan merumuskan masalah penelitian, menyusun hipotesis penelitian), termasuk juga memilih jenis analisis statistik dengan menggunakan SPSS yang akan dipakai. Di 
samping itu, konsep-konsep kunci dalam penelitian seperti validitas, reliabilitas, dan sebagainya juga diperkenalkan kepada guru-guru.

\section{HASIL DAN PEMBAHASAN}

Pelatihan pelaksanaan penelitian tindakan kelas dengan analisis statstik menggunakan SPSS, ditujukan untuk meningkatkan kemampuan untuk menyusun proposal penelitian tindakan kelas. Setelah mengikuti pelatihan tersebut diharapkan para guru akan dapat menghasilkan proposal penelitian tindakan kelas. Minimal guru-guru SMK Santo Leo dapat mempelajari kembali dari materi yang disampaikan dalam Webinar pelaksanaan PKM dan menggunakan aplikasi SPSS yang telah disampaikan.

Dengan menggunakan software SPSS yang ternyata belum banyak dikenal oleh para guru SMK Santo Leo, terdapat kesulitan dalam penyampaian materi. Namun kepala sekolah sudah pernah mengetahui tentang software SPSS dan pernah menggunakannya, dan tahu kemudahan yang dapat diperoleh dengan running data menggunakan software SPSS.

Meski software tidak dipersiapkan oleh sekolah, namun maksimal tim PKM telah berupaya untuk memberikan yang terbaik dan hal ini disambut baik oleh kepala sekolah SMK Santo Leo.

Pengabdian kepada masyarakat (PKM) adalah kegiatan yang sangat didukung penuh oleh perguruan tinggi seperti Universitas Tarumanagara melalui pendanaan yang diberikan kepada tim pengusul PKM. Tim pengusul PKM adalah tim yang telah memperoleh sertifikasi dosen, sehingga setiap semester harus melakukan Tri Dharma Perguruan Tinggi, yang salah satunya adalah kegiatan PKM.

Pelaksanaan penelitian tindakan kelas terhadap guru SMK Santo Leo pada dasarnya mengacu pada penguasaan teori Metodologi Penelitian. Untuk itu, kepakaran dalam hal metodologi penelitian sangat diperlukan. Dalam hal ini, ke-4 anggota dari tim PKM, dua diantaranya sudah memiliki gelar Doktor, dan sebagai staf pengajar Metodologi Penelitian, pengajar mata kulaih Statistik, baik pada penelitian kuantitatif maupun penelitian kualitatif. Selain itu seluruh anggota tim berprofesi sebagai dosen, yang selama ini telah beberapa kali melakukan penelitian dalam bidangnya masingmasing dan didampingi seorang mahasiswa yang diikutsertakan untuk dapat belajar dan membantu dosen PKM dalam menjalankan pengabdian masyarakat.

Secara umum, hasil yang diperoleh dari kegiatan PKM ini adalah semua guru mengikuti pelatihan menyatakan berguna dan memperoleh pengetahuan tentang penelitian tindakan kelas. Dan itu terlihat dari evaluasi kuesioner yang telah disampaikan untuk diisi oleh guru.

Hasil evaluasi menggunakan kuesioner melalui google form menunjukkan bahwa:

1. Topik yang diberikan sangat berguna

2. Topik penyuluhan membuka wawasan guru

3. Peserta dapat belajar banyak dari penyuluhan ini

4. Topik penyuluhan memotivasi untuk melakukan PTK

5. Topik penyuluhan ini jarang dilakukan di sekolah tempat guru mengajar

6. Pembicara dalam tim PKM menguasai materi

7. Pembicara memberikan kesempatan berdiskusi

8. Materi/artikel disampaikan dan diberikan kepada seluruh peserta

9. Pembicara dapat memberikan jawaban atas pertanyaan yang diajukan peserta

Tetapi harus diakui bahwa PKM pelatihan penelitian tindakan kelas ini bukan tanpa kendala, pertemuan yang sudah dijadwalkan ternyata ditunda untuk dilaksanakan dan para guru masih memiliki kesibukan lain. Di samping itu, guru-guru juga memiliki akses internet yang terbatas. 
Pada akhirnya kegiatan PKM ini sendiri dilakukan pada tanggal 24 Juli 2020. Dengan kondisi pandemic Covid-19 saat ini, memang untuk mendapatkan hasil maksimal seperti yang diharapkan tidak dapat terpenuhi. Tetapi dari hasil pelaksanaan penyuluhan berdasarkan informasi kepala sekolah SMK Santo Leo, mereka sangat mengapresiasi kehadiran tim PKM UNTAR dalam pelaksanaan Webinar PKM bagi guru-guru SMK Santo Leo yang setiap hari masuk sekolah dan hadir di SMK Santo Leo Mangga Besar.

Meski situasi masih dalam kondisi pandemic covid, persiapan yang semula sudah dilakukan mulai dari bulan Februari 2020, namun pelaksanaan baru benar-benar dapat dilakukan pada 24 Juli 2020. Sangat bersyukur karena benar-benar akhirnya dapat terlaksana dengan baik. Kerjasama dengan kepala sekolah Ibu Yayuk Hartiwi dan guru Ibu Margaretha, pelaksanaan PKM dapat terwujud dengan baik dan lancar menggunakan aplikasi Zoom. Semula IT sekolah menyediakan google meet untuk pelaksanaan, namun pihak sekolah yang masih menjalankan periode belajar mengajar, akhirnya menyerahkan pilihan kepada tim PKM untuk menyediakan aplikasi yang tepat untuk pelaksanaan penyuluhan PKM.

Pelaksanaan dilakukan secara online dan interaktif. Sharing penelitian disampaikan oleh tim PKM FEB secara bergantian yang disertai dengan tanya jawab dengan guru-guru. Beberapa pertanyaan interaktif yang muncul antara lain:

1. Dari Kepala Sekolah: Dra. Theresia Yayuk Hartiwi; sering kita memberikan pujian pada siswa, dan pengaruh secara kualitatif siswa lebih termotivasi, tetapi selama ini belum pernah melakukan secara ilmiah saat ini kami belum tahu cara analisisnya. Mohon petunjuk metode yang paling mudah.

2. Dari Pak FX Harsana; Mohon dijelaskan kembali yang dimaksud dengan intervensi.. kalua di dunia sekolah.. sebaiknya bagaimana?

3. Dari Pak Bambang Parmono; cara memberi stimulus siswa agar senang dengan program PJJ.

\section{KESIMPULAN DAN SARAN \\ Kesimpulan}

Persoalan yang dialami para guru SMK Santo Leo Jakarta adalah kurangnya pengetahuan dan keterampilan dalam melakukan penelitian dengan memanfaatkan SPSS. Sebagai solusinya adalah dilakukan PKM Pelatihan Penelitian Tindakan Kelas bagai para guru. PKM Pelatihan Penelitian Tindakan Kelas dengan Menggunakan SPSS bagi Guru-guru SMK Santo Leo berhasil meningkatkan pengetahuan dan keterampilan para guru dalam melakukan penelitian tindakan kelas menggunakan SPSS. PKM Pelatihan ini sangat berguna dan membuka wawasan guru untuk dapat menggunakan analisis statistik sebagai alat penelitian tindakan kelas. Pengetahuan dasar tentang analisis statistik seperti regresi, korelasi, dan sebagainya dengan menggunakan software SPSS meningkatkan semangat para guru untuk meneliti dan memperbaiki mutu proses pembelajaran di kelas.

\section{Saran}

Beberapa masukan dari peserta guru, menghendaki periode selanjutnya bila ada tim penyuluh yang akan memberikan penyuluhan atau pun pelatihan agar tetap dapat dilakukan di sekolah meski kondisi pandemic, karena yang hadir di sekolah hanya guru dan jumlahnya tidak sebanyak bila siswa turut hadir secara fisik di sekolah.

Apabila menggunakan internet, kadang terkendala wifi sekolah maupun kendala perangkat guru yang tidak memadai pada kondisi saat pelaksanaan. 
Materi untuk latihan diberikan contoh yang paling mendekati kondisi yang dialami guru dalam Pendidikan siswa, meski level atau jenjang siswa berbeda pada masing-masing kelas.

Ucapan Terima Kasih (Acknowledgement)

Kami ingin mengucapkan terima kasih kepada Ketua Lembaga Penelitian dan Pengabdian Kepada Masyarakat (LPPM) Universitas Tarumanagara atas kesempatan dan dukungan dana operasional yang diberikan kepada kami sehingga kami dapat melakukan kegiatan pengabdian kepada masyarakat di SMK Santo Leo Jakarta. Tak lupa kami juga mengucapkan terima kasih kepada Kepala Sekolah SMK Santo Leo yang telah memberikan kesempatan kepada tim PKM Untar untuk melaksanakan penyuluhan dan pelatihan penelitian tindakan kelas ini.

\section{REFERENSI}

Arikunto, Suhardjono dan Supardi. (2006). Penelitian Tindakan Kelas. Jakarta: Bumi Aksara.

Czarl, A. and M. Belovecz. (2007). Role of Research and Development in the 21th Century. Revista Informatica Economica, 4 (44).

Hopkins, David. (1993). A Teacher's Guide to Classroom Research. Philadelphia: Open University Press.

Mulyatiningsih, Endang. (2011). Metode Penelitian Terapan Bidang Pendidikan. Bandung: Alfabeta.

Peraturan Menteri Pendidikan Nasional Nomor 16 Tahun 2007 tentang Standar Kualifikasi Akademik dan Kompetensi Guru. Diperoleh tanggal 24 Januari 2018, dari https://luk.staff.ugm.ac.id/atur/bsnp/Permendiknas16- 2007KompetensiGuru.pdf

Rahayu, S. (2007). Menumbuhkan minat meneliti guru dengan penelitian tindakan kelas. Efisiensi: Kajian ilmu administrasi. Vol. VII No. 2 100-110, dari https://journal.uny.ac.id/index.php/efisiensi/article/view/3919

Undang-Undang Republik Indonesia Nomor 14 Tahun 2005 Tentang Guru dan Dosen. Diperoleh tanggal 24 Juli 2017, dari https://disdik.bandung.go.id/2017/wpcontent/uploads/2017/02/Permendiknas-No-16-Tahun-2007.pdf

Wardani, I.G.A.K. (2014). Modul 1. Hakikat Penelitian Tindakan Kelas. Diperoleh tanggal 24 Juli 2017. http://repository.ut.ac.id/4153/1/IDIK4008-M1.pdf

Weil, David N. (2009). Economic Growth. Singapore: Pearson-Addison Wesley.

Yuliwati, F., Suprihatiningrum, J., Rokhimawan, M.A. (2012). Penelitian Tindakan Kelas untuk Tenaga Pendidik Profesional. Yogyakarta: Pedagogia. PT Pustaka Insan. 